\title{
Physicochemical characteristics of shea kernels and kinetics of shea butter press extraction
}

\author{
Mohagir, A. M. ${ }^{a^{*}}$, Bup Nde.D ${ }^{b}$, Ahmat-Charfadine M. ${ }^{a}$, Kamga, R. ${ }^{c}$ and Kapseu, C. ${ }^{c}$ \\ ${ }^{a}$ Faculty of Science and Technologies, University of Sarh, P.O. Box 105, Chad \\ amohagir2003@yahoo.fr \\ ${ }^{\mathrm{b}} \mathrm{Higher}$ Institute of the Sahel, University of Maroua, Cameroon \\ bupdiv@yahoo.fr \\ ${ }^{c}$ National School of Agro- Industries Science, University of Ngaoundere, Cameroon \\ richkamga@yahoo.fr
}

\begin{abstract}
Morphological study of some non conventional oil seeds are of great interest for the development of some communities. In this investigation, shea kernels from 4 localities in Chad were studied. The sun dried shea kernels from Beinamar locality had the greatest length $(28.30 \pm 3,25 \mathrm{~mm})$, diameter $(20.58 \pm 2.46 \mathrm{~mm})$, weight $(5.56 \pm 1.52 \mathrm{~g})$ and moisture content $(3.79 \pm 0.14$ $\%$ ), whereas the kernels of Penie village had the least values $(24.25 \pm 2.54,19.02 \pm 2.34,4.0 \pm 1.01$ and $3.54 \pm 0.33$ respectively) of the mentioned characteristics. On the other hand, the total lipid content of Penie's shea kernels was the highest $(58.5 \%)$ whereas that of Bolo village was the lowest one $(53.53 \pm 0.40 \%)$. The acid value of the 4 samples was extremely high ( $25.31 \pm 0.71-38.30 \pm 0.76 \mathrm{mg} \mathrm{KOH} / \mathrm{g}$ oil), whereas the acid value of the oven dried shea kernels produced using boiling method was low $(1.2-2.1)$. The kinetics of press extraction of shea butter suggested that the extraction time is 12 min.
\end{abstract}

Keywords: shea; kernels; butter; boiling; physicochemical characterization; correlation; extraction; kinetics.

*Corresponding author email: amohagir2003@yahoo.fr

\section{Council for Innovative Research}

Peer Review Research Publishing System

Journal: Journal of Advances in Chemistry

Vol. 10, No. 3

editorjaconline@gmail.com

www.cirjac.com 


\section{Introduction}

In developing countries, one of the ways of promoting development is through the exploitation of available local resources. This also helps to satisfy the needs of the increasing population and increase the income of the citizen [1].

Though several studies have been carried out on the physicochemical and functional properties of shea kernels as under exploited oilseeds elsewhere [2-4], there is very little information on the physicochemical characteristics of shea kernel in the producing countries in general and in Chad in particular. Meanwhile, Mbaiguinam et al., (2007) [5] reported some morphological as well as some physicochemical characteristics of shea tree and shea fruit in the southern region of Chad. Their study was done in one production area (Mandoul region). But Palmberg (1985) [6] reported that to study different properties of certain species, sampling site should be as far as possible so as to account for the influence of some parameters such as site, climate and ecology. Therefore, this part of research was focused on the determination of the morphological and the physicochemical characterisation of sun dried shea kernels from different localities in the southern region of Chad, and to study the kinetics of press extraction of shea butter, because the annual production of Chadian shea kernels was estimated to be 1390247 tons, with about $40 \%$ post harvest losses [7]. Therefore, 834148 tons per year could be transformed to shea butter. Shea butter is used as an edible vegetable fat in many African countries. It can be utilized as a substitute or complete replacement for cocoa butter in various applications and plays an important role in traditional African medicinal practice [8].

\section{Materials and methods}

\section{1. Origin and characterisation of shea kernels}

Sun dried shea kernels which were produced using the non boiling method described by Adoum (1996) [9] were bought from: Beinamar locality west of Mondou city, Bedjondo village $45 \mathrm{~km}$ east of Doba city, Penie village $35 \mathrm{~km}$ west of Koumra city and Bolo village $27 \mathrm{~km}$ east of Kelo city. These sites are located in southern region of Chad in Sudanian zone (Savannah's trees). The selection of these localities was based on two reasons; first, they present the main source of supply of sun dried shea kernels to local markets. Secondly, there is a lack of information on morphological characteristics of sun dried shea kernels and on the physicochemical properties of shea butter from these localities. Some geographical information (height above see level, longitude, latitude, rainfall and the type of soil) for each site are shown in table 1 [10-11]. For the purpose of comparisons, oven dried shea kernels produced following the boiling method as described by Lovett (2004) [12] were prepared from shea fruits.

Table 1: Some geographical information about the four localities in southern Chad

\begin{tabular}{lllll}
\hline Geographical information & Bolo & Locality & & Penie \\
\hline Height (m) & 375 & 410 & Bedjondo & 393 \\
Longitude (east) & $16^{\circ} .00$ & $15^{\circ} .25$ & 387 & $17^{\circ} .05$ \\
Latitude (north) & $9^{\circ} .20$ & $8^{\circ} .40$ & $8^{\circ} .35$ & $8^{\circ} .50$ \\
Rainfall (mm) & 1000 & 1100 & 1150 & 1100 \\
Type of soil & $\begin{array}{l}\text { Reddish brown (Kaolinite, } \\
\text { hematite) }\end{array}$ & $\begin{array}{l}\text { Red soil } \\
\text { (ferruginous) }\end{array}$ & $\begin{array}{l}\text { Reddish } \\
\text { (hydromorphic) }\end{array}$ & $\begin{array}{l}\text { Brown (higher } \% \text { of } \\
\text { clay fraction) }\end{array}$ \\
\hline
\end{tabular}

\section{2. Preparation of oven dried shea kernels using boiling method}

Ripe shea fruits from Bolo and Bedjondo villages were collected and brought to the laboratory of Applied Chemistry Faculty of Pure and Applied Sciences University of N'Djamena Chad. The fruits were depulped and each sample was divided in two equal lots, one lot was boiled (Bo) in water for one hour and the other was kept un boiled (NBo). Then all the samples were dehulled and dried in an oven $\left(60 \pm 2^{\circ} \mathrm{C}\right)$ for 72 hours.

The diameter and length of 100 sun dried shea kernels (randomly selected) from each of the four localities were determined using Vernier callipers. The mass was measured using a laboratory balance of 0.001 precision. The moisture content (\%) of the kernels was determined using AFNOR, (1981) method. In this method, $5 \mathrm{~g}$ of ground kernels was placed in a dry oven dish, and then dried in an oven at $105 \pm 2^{\circ} \mathrm{C}$ until a constant mass was achieved. The experiment was repeated twice and the average value was taken.

The moisture content $M_{c}$ was calculated on a wet basis and expressed in gram per 100 grams of initial sample (equation 1).

$$
\mathrm{M}_{\mathrm{c}}=\frac{\mathrm{m}_{1}-\mathrm{m}_{2}}{\mathrm{~m}_{1}} * 100 \%
$$

Where $m_{1}$ is the mass in gram of wet sample and $m_{2}$ is the mass of dry sample. 


\section{3. Shea butter extraction}

Solvent extraction method was used to determine the total lipid content and the later was used to determine the extraction yield of press extracted shea butter.

\section{3. 1. Determination of the total lipid content}

The total lipid content represents the total fats in the oil seed. The method used was described in IUPAC (1979) [13]. This method is based on the differential solubility of lipid in the organic solvent ( $n$-hexane or petroleum ether). The extraction was done in a soxhlet apparatus for 8 hours, after which the solvent was evaporated and the fat was dried in the oven. The detailed procedure is as follows:

$20 \mathrm{~g}$ of ground shea kernels was introduced in a dry cellulose thimble. The thimble was put in the extraction flask and then $250 \mathrm{ml}$ of petroleum ether was added. The extraction flask was then fitted onto the soxhlet and the extraction was conducted for 8 hours. After this period the flask was removed and the solvent was evaporated from the mixture using rotary evaporator. The extracted oil was then dried in the oven at $105 \pm 2{ }^{\circ} \mathrm{C}$ for one hour, then cooled in a crucible for 30 minutes and weighed. The experiment was repeated twice and the average mass was taken.

The lipid content $\left(L_{c}\right)$ as a percentage of dry material was expressed by equation 2 .

$$
\mathrm{L}_{\mathrm{c}}=\frac{\mathrm{m}_{1}-\mathrm{m}_{0}}{\mathrm{~m}} * 100 * \frac{100}{100-\mathrm{M}_{\mathrm{c}}}
$$

Where $m_{1}$ is the mass of extraction flask containing the oil after oven drying together with beads, $m_{0}$ is the mass of the empty flask with beads inside, $m$ is the mass of initial ground kernels and $M_{c}$ is the moisture content of the sample.

\section{3. 2. Press extraction}

For the press extraction of shea butter a manual hydraulic press of model "MF-FSEA-2005" constructed in the Department of Technology of the Faculty of Pure and Applied Sciences (University of N'djamena) was used. This press was constructed based on the press (model KCT 2000 AIRE) described by Tchiegang et al. (2003) [14]. The press (Figure 1) is composed of a horizontal metal arm (1) joint with a vertical screw rod (2). The later is passed through a node (3) which is fixed to a frame (4). The screw rod ends on a pressing disc at its lip (5). The disc passes through a perforated external cylinder (6) which is welded to a fixed plate (7). An internal perforated cylinder and the oil recipient (8) are complementary parts.

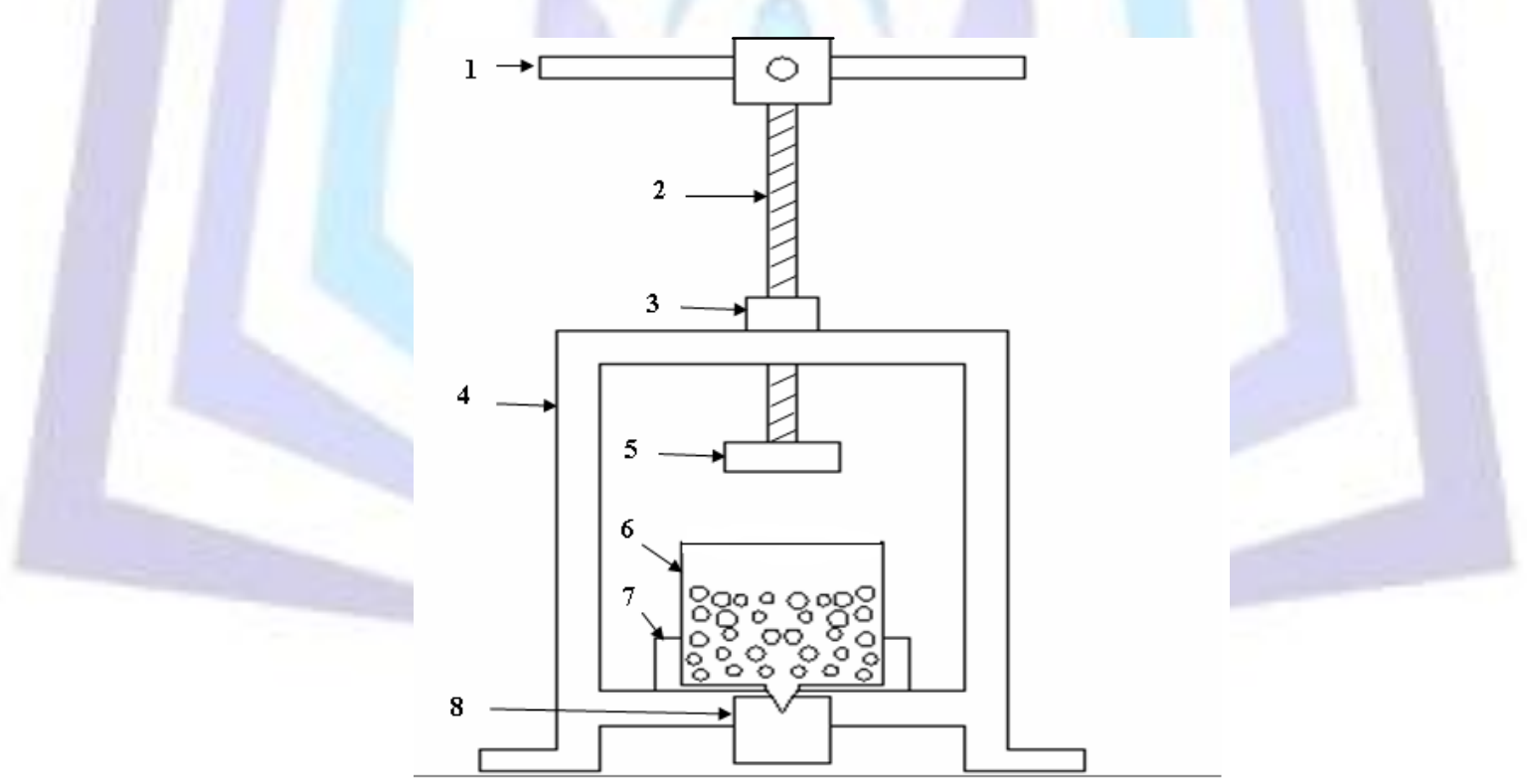

Figure 1: Sketch of a manual vertical screw press of model "MF-FSEA-2005": Horizontal metal arm (1), vertical screw rod (2), node (3), frame (4), pressing disc (5), perforated external cylinder (6), fixed plate (7) and oil recipient (8).

The support of the press was inclined at $20^{\circ}$ to the horizontal to permit the flow of the shea butter at its melting point ( 40 $50^{\circ} \mathrm{C}$ ) and this was achieved by heating $\left(\right.$ about $60^{\circ} \mathrm{C}$ ) the fixed plate before pressing. In each experiment, the shea kernels were ground and then put in a dry $100 \mathrm{ml}$ beaker and covered tightly with aluminium sheet. The beaker and its contents was immersed into boiling water for 30 minutes (steam cooking) while ensuring that there was no direct contact of the water with the ground sample. A known quantity of the cooked sample was put in a cotton bag and placed in the internal cylinder in the press. Then the pressing disc was screwed down slowly inside the cylinder by rotating the horizontal metal arm up to a certain level determined by a point in the vertical screw rode beyond which the system will collapse. Oil which escapes through the perforations was collected in recipient, weighed and kept for further analysis. Using the barometer and hydraulic press, 
moving the same distance mentioned latter, the pressure measured was found to vary between 17 and $18 \mathrm{M}$ Pa. The dimensions of this press are figured in table 2 .

Table 2: Dimensions of different parts of the manual hydraulic press of model "MF-FSEA-2005”.

\begin{tabular}{ll}
\hline The part & Dimensions $\mathbf{( c m )}$ \\
\hline Horizontal bar & Length $=42 ;$ diameter $=2$ \\
Vertical screw rod & Length $=44$; diameter $=3$ \\
Frame & Length $=33$; width $=30$; thickness $=6$ \\
Pressing disk & Diameter $=5$ \\
External perforated cylinder & Internal diameter $=6.5 ;$ height $=10.5 ;$ thickness $=0.8$ \\
Internal perforated cylinder & Internal diameter $5.2 ;$ height $=7.5 ;$ thickness $=0.5$ \\
Fixed plate & Length; $15.6 ;$ width: $10 ;$ height: 5
\end{tabular}

The quantity of the oil recovered from the ground shea kernels $\left(Y_{\text {ield }}\right)$ was calculated as a ratio of the mass of the extracted oil to the mass of dry sample (equation 3 ), while the effective yield ( $E_{\text {ield }}$ ) was calculated from the ratio of the amount of extracted oil to the total amount of oil available $\left(L_{c}\right)$ in the sample (equation 4$)$.

$$
\begin{aligned}
\mathrm{Y}_{\text {ield }} & =\frac{\mathrm{M}_{0}(\mathrm{~g})}{\mathrm{M}_{\mathrm{d}}(\mathrm{g})} * 100 \\
\mathrm{E}_{\text {ield }} & =\frac{\mathrm{Y}_{\text {ield }}}{\mathrm{L}_{\mathrm{c}}} * 100
\end{aligned}
$$

Where $M_{0}$ is the mass of oil recovered in gram, $M_{d}$ is the mass of dry sample; $L_{c}$ is the total lipid content.

For the kinetics study, raw sun dried shea kernels were used. The kernels were ground and sieved using sieves of 2 - $3 \mathrm{~mm}$ square mesh, steamed cooked for $30 \mathrm{~min}$ in a water bath and then pressed. Each experiment was replicated twice and the average values were taken. Extractions were done for 3, 6, 12, 15 and $18 \mathrm{~min}$. The yield of shea butter from the four samples, as a function of extraction time was then plotted.

\section{4. Shea butter characterisation}

\section{4. 1. Acid value}

The acid value is defined as the milligrams of potassium hydroxide required to neutralise the free carboxyl groups in one gram of oil or fat. The method used for the determination of acid value was described in (AFNOR, 1981) [15]. The determination of acid value is based on the dissolution of a known quantity of fat in a mixture of $95 \%$ ethanol and diethyl ether $1: 1(\mathrm{v} / \mathrm{v})$, followed by the titration of FFAs with ethanolic solution of $\mathrm{KOH}$ in the presence of $1 \%$ phenolphthalein solution in $95 \%$ ethanol as indicator.

The procedure was as follows: $1 \mathrm{~g}$ of fat was weighed in $250 \mathrm{ml}$ conical flask, then $10 \mathrm{ml}$ of the mixture of $95 \%$ ethanol and diethyl ether was added to the beaker with shaking, then three drops of the phenolphthalein solution were added. The mixture was titrated with ethanolic solution of $\mathrm{KOH}(0.5 \mathrm{~N})$, and then a blank test was carried out. Each experiment was repeated twice and the average values were calculated. The acid value $\left(A_{v}\right)$ was expressed by equation 5

$$
\mathrm{A}_{\mathrm{V}}=\frac{56.1 \mathrm{~N}\left(\mathrm{~V}-\mathrm{V}_{0}\right)}{\mathrm{m}}
$$

Where $\mathrm{V}$ is volume of $\mathrm{KOH}$ solution used in the titration of test portion, $\mathrm{V}_{0}$ is the volume of the $\mathrm{KOH}$ solution used in the blank test, $\mathrm{N}$ is the exact normality of $\mathrm{KOH}$ solution, $m$ is the mass of the test sample.

Free Fatty Acid (FFA) is the equivalent of oleic acid content of the fat. It is about one-half $(0.504)$ the acid value. Both characteristics indicate the quality of the oil with respect to acidity, and have been used to follow the course of fat or oil refining [16].

$$
\underset{\text { Fatty acid }}{\mathrm{R}-\mathrm{COOH}}+\mathrm{KOH} \rightarrow \underset{\text { Soap }}{\mathrm{R}}-\underset{\mathrm{COOK}}{\mathrm{C}}+\mathrm{H}_{2} \mathrm{O}
$$




\section{4. 2. Peroxide value}

Peroxide value is used to determine the degree of oxidation of oil and fats. It is defined as the content of reactive oxygen in terms of milligrams of fat (1 millimole $=2 \mathrm{ml}$ equivalent) or $\mathrm{ml}$ equivalent of oxygen per kilogram of fat. The primary oxidation products of oils and fats are hydroperoxides. The amount of hydroperoxides is quantitatively measured by determining the amount of iodine liberated by its reaction with $\mathrm{KI}$. The technique used is phenolphthalein method described in AFNOR, (1981) [15].

The procedure is detailed as follows: In each experiment, $2 \mathrm{~g}$ of the fat sample was weighed into $250 \mathrm{ml}$ conical flask and dissolved by adding $10 \mathrm{ml}$ of chloroform with shaking. Then $15 \mathrm{ml}$ of acetic acid and $1 \mathrm{ml}$ of saturated solution of $\mathrm{KI}$ were added successively to the flask, then it was stoppered immediately, shaken for one minute and kept in the dark for 5 minutes after which $75 \mathrm{ml}$ distilled water was added and the content of the flask was titrated with sodium thiosulphate solution (0.01 N) in the presence of starch solution as indicator. Each experiment was repeated twice. At the end a blank test was carried out and the peroxide value $\left(P_{\mathrm{v}}\right)$ was expressed by equation 6 .

$$
\mathrm{P}_{\mathrm{V}}=\frac{1000 \mathrm{~N}\left(\mathrm{~V}-\mathrm{V}_{0}\right)}{\mathrm{m}}
$$

Where $\mathrm{N}$ is the normality of sodiumthiosulphate solution, $\mathrm{V}$ is the volume of sodiumthiosulphate used for the test with the fat, $V_{0}$ is the volume of sodiumthiosulphate used for the blank test and $\mathrm{m}$ is the mass in gram of the test sample.

\section{Results and discussion}

\section{1. Some physicochemical characteristics of shea kernels and shea butter}

The determination of some characteristics of sun dried shea kernels was done with the objective to making available information on this commodity which is produced in different areas in the southern region of Chad. The results are presented in table 3

Table 3: Some physicochemical characteristics of raw sun dried shea kernels and shea butter from four localities in the southern region of Chad

\begin{tabular}{|c|c|c|c|c|}
\hline \multirow[b]{2}{*}{ Characteristic } & \multicolumn{2}{|r|}{ Locality } & & \multirow[b]{2}{*}{ Penie } \\
\hline & Bolo & Beinamar & Bedjondo & \\
\hline Length (mm) & $26.1^{b} \pm 3.6$ & $28.3^{\mathrm{C}} \pm 3.3$ & $25.4^{\mathrm{b}} \pm 2.8$ & $24.3^{\mathrm{a}} \pm 2.5$ \\
\hline Diameter (mm) & $19.3^{\mathrm{a}} \pm 2.4$ & $20.6^{c} \pm 2.5$ & $19.2^{\mathrm{a}} \pm 2.0$ & $19.0^{\mathrm{b}} \pm 2.3$ \\
\hline Weight (g) & $4.80^{\mathrm{b}} \pm 1.7$ & $5.6^{c} \pm 1.5$ & $4.5^{b} \pm 1.0$ & $4.0^{a} \pm 1.0$ \\
\hline Moisture content & $3.68^{a} \pm 0.21$ & $3.79^{a} \pm 0.14$ & $3.69^{a} \pm 0.27$ & $3.54^{a} \pm 0.33$ \\
\hline Total lipid content (\%) & $53.53^{\mathrm{a}} \pm 0.40$ & $55.10^{b} \pm 0.73$ & $56.59^{c} \pm 0.44$ & $58.45^{d} \pm 0.23$ \\
\hline Acid value & $38.30^{c} \pm 0.76$ & $25.30^{a} \pm 0.71$ & $33.66^{b} \pm 0.21$ & $25.81^{a} \pm 0.78$ \\
\hline
\end{tabular}

Means in the same row with different superscripts are significantly different $(p<0.05)$

The mean and the standard deviations for the physicochemical properties of shea kernels and shea butter in table 3 were calculated from the randomly selected 100 sun dried shea kernels from each locality. The moisture content for the four samples is lower than the optimum one (10-15\%) required for optimum storage which was reported by EL Warraki, (1995) [17]. Also, from table 3 it is observed that the acid value of the shea kernel samples from the 4 localities is extremely higher than that permitted for edible oils and fats [18]. These higher values of acidity are an indication of oil degradation in the shea kernels during the process of sun drying.

Also it is observed that the sun dried shea kernels from Beinamar locality has the highest length, diameter, weight and moisture content, whereas the kernels of Penie village has the least values of the mentioned characteristics. It is observed that, sun dried shea kernels obtained from the highest locality $(410 \mathrm{~m})$ characterised by larger diameter, length and weight, while that from the lowest locality $(365 \mathrm{~m})$ characterised by small diameter, length and weight. The Pearson correlation coefficients between the diameter, length and the weight of shea kernels and the height, longitude, latitude and rain fall of the sites, showed that, the diameter, length and the weight of the kernel were positively correlated to the height and negatively to the longitude of the sampling site. The low correlation appeared in table 4 is due to the small variation in the height. 
Table 4: Correlation coefficients between some geographical parameters and physical characteristics of sun dried shea kernels obtained from 4 localities in southern Chad.

\begin{tabular}{|c|c|c|c|c|c|c|c|}
\hline & Height (m) & Longitude (east) & Latitude (north) & Rainfall (mm) & Diameter & Length & Weight \\
\hline Height (m) & 1,00 & $-0,25$ & $-0,84$ & 0,65 & 0,17 & 0,18 & 0,14 \\
\hline Longitude (east) & $-0,25$ & 1,00 & $-0,23$ & 0,41 & $-0,23$ & $-0,41$ & $-0,38$ \\
\hline Latitude (north) & $-0,84$ & $-0,23$ & 1,00 & $-0,96$ & $-0,06$ & $-0,01$ & 0,01 \\
\hline Rainfall (mm) & 0,65 & 0,41 & $-0,96$ & 1,00 & 0,00 & $-0,06$ & $-0,07$ \\
\hline Diameter & 0,17 & $-0,23$ & $-0,06$ & 0,00 & 1,00 & 0,60 & 0,79 \\
\hline Length & 0,18 & $-0,41$ & $-0,01$ & $-0,06$ & 0,60 & 1,00 & 0,83 \\
\hline Weight & 0,14 & $-0,38$ & 0,01 & $-0,07$ & 0,79 & 0,83 & 1,00 \\
\hline
\end{tabular}

On the other hand, based on the total lipid content, shea kernels from Penie had the highest value (58.5\%). This value is close to that reported by Tano Debrah and Ohta (1994) in Ghana (59\%). The variation in the total lipid content from one locality to another is usually attributed to the diversity in natural soil and composition of their derivation or other manmade cumulative effects, in addition to the possible change in environmental and geological conditions from one region to another [19].

Moisture and lipid content of shea kernel, together with the acid and peroxide values of extracted shea butter from Bolo and Bedjondou villages are reported in table 5.

Table 5: Some physicochemical characteristics of shea kernels and of shea butter obtained using boiling and oven drying method.

\begin{tabular}{lll|ll}
\hline \multirow{3}{*}{ Parameter } & \multicolumn{4}{c}{ Origin of the sample } \\
\cline { 2 - 5 } & Bolo NBo & Bolo Bo & Bedjondou NBo & Bedjondou Bo \\
\hline Moisture content (\%) & $7.50^{\mathrm{a}} \pm 0.17$ & $8.60^{\mathrm{b}} \pm 0.22$ & $4.22^{\mathrm{a}} \pm 0.37$ & $6.12^{\mathrm{b}} \pm 0.32$ \\
Lipid content (\%) & $45.96^{\mathrm{a}} \pm 1.06$ & $53.14^{\mathrm{b}} \pm 0.87$ & $40.57^{\mathrm{a}} \pm 0.84$ & $45.14^{\mathrm{b}} \pm 1.21$ \\
Acid value & $2.10^{\mathrm{a}} \pm 0.49$ & $1.40^{\mathrm{a}} \pm 0.60$ & $1.40^{\mathrm{a}} \pm 0.67$ & $1.21^{\mathrm{a}} \pm 0.50$ \\
Peroxide value & $2.13^{\mathrm{a}} \pm 0.16$ & $7.38^{\mathrm{b}} \pm 0.21$ & $2.63^{\mathrm{a}} \pm 0.18$ & $5.13^{\mathrm{b}} \pm 0.14$
\end{tabular}

Means in the same row for the same locality with different superscripts are significantly different ( $p<0.05) ;$ NBo: Un boiled; Bo: Boiled

From table 5 it is noticed that boiling of shea nuts in water for 60 min significantly increased the moisture content of shea kernels, increased the extraction yield, increased the peroxide value and decreased the acid value of shea butter. The observed increase in the moisture content of shea kernels could be attributed to the absorption of water by the kernel during the boiling process, while the increase of the peroxide value could be relatively attributed to the oxidation of shea butter during boiling process. These results agree well with those reported by Womeni et al. (2006) [20]. The increase in extraction yield as a result of boiling of shea nut could be attributed to denature of proteins. This action reduces the affinity of oil for solid surfaces and therefore oil could flow out easily as confirmed by Norris (1982) [21].

The decrease in acid value by boiling process might be due to the deactivation of lipase enzymes that naturally exist in oilseeds. Lipase catalyses the hydrolysis of oil in oilseeds and liberates free fatty acids. Ladurelle (1984) [22] reported that lipases in oilseeds can be deactivated at $80^{\circ} \mathrm{C}$ after an hour or at $100^{\circ} \mathrm{C}$ after $10 \mathrm{~min}$.

Generally, it could be reported that the acid value of shea butter that was produced using the boiling method and oven drying of shea kernels, is low compared with that of shea butter produced using non boiling method and sun drying. In addition, boiling significantly improved the extraction yield of shea butter.

\section{2. Kinetics of press extraction of shea butter}

The kinetic curve was found to follow equation 7 (exponential rise to maximum).

$$
\mathrm{y}=a\left(1-e^{-b t}\right)
$$

Where $\mathbf{y}$ is the yield $(\mathrm{g} / \mathrm{g})$, $\mathbf{t}$ extraction time ( $\mathrm{min})$, $\mathbf{a}$ and $\mathbf{b}$ are constants.

From figure 2, it is observed that the extraction rate of shea butter from the sun dried shea kernels seemed to be very fast in the first 3 minutes, and then it had a moderate increment in the next 9 minutes. After 12 minutes the rate was almost constant. This behaviour was supported by the results of $y_{t} / y_{t-3}$ appeared over figure 2 in which $y_{9} / y_{12}$ gave $95 \%$ oil yield. Also it is noticed that Penie sun dried shea kernels gave the best yield of shea butter, followed by Beinamar sample. In fact, from 
the kinetic plots, the yield was related to the total lipid content. These results permitted us to select the sample of Penie locality for the optimisation of press extraction process.

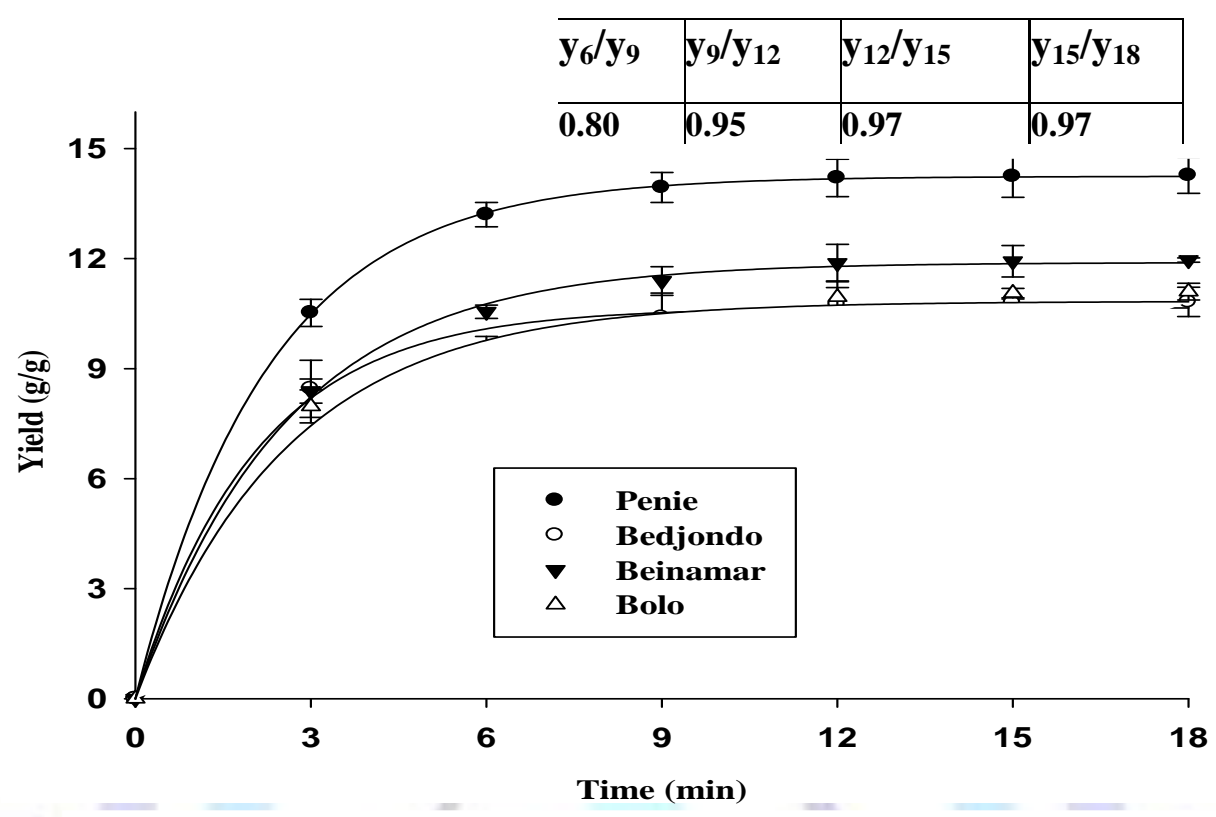

Figure 2: Variation of yield and press extraction time of shea butter

\section{CONCLUSION}

This study permitted us to conclude that the sun dried shea kernels from Beinamar locality has the biggest size: length (28.30 $\pm 3,25 \mathrm{~mm})$, diameter $(20.58 \pm 2.46 \mathrm{~mm})$, weight $(5.56 \pm 1.52 \mathrm{~g})$ and moisture content $(3.79 \pm 0.14 \%)$, whereas the kernels from Penie village are the smallest in size: (24.25 $\pm 2.54,19.02 \pm 2.34,4.0 \pm 1.01$ and $3.54 \pm 0.33$ respectively). On the other hand, based on the total lipid content, Penie's shea kernels have the highest $(58.5 \%)$ and Bolo village showed the lowest $(53.53 \pm 0.40 \%)$.

The acid value of the 4 samples of sun dried shea kernels is extremely high $(25.31 \pm 0.71-38.30 \pm 0.76)$, whereas the acid value of the oven dried shea kernels produced using boiling method is low (1.2 - 2.1). The kinetics of press extraction of shea butter suggested that the equilibrium extraction time is $12 \mathrm{~min}$.

\section{ACKNOWLEDGMENT}

This work is supported by the French Government through EGIDE program (Centre Français pour l'Accueil et les Echanges Internationaux).

\section{REFERENCES}

[1] Achu, M.B., E. Fokou, C. Tchiegang, M. Fotso and F.M. Tchouanguep, 2005. Nutritive value of some cucurbitaceae oilseeds from different regions in Cameroon. Af. J. Biotechnol., 4: 1329-1334.

[2] Tano-Debrah K., and Ohta Y., 1994, Enzyme-assisted aqueous extraction of fat from kernels of shea butter tree (Butyrospermum parkii ), J. Am. Oil. Chem. Soc., 71: 979-983

[3] Kapseu C., Dirand M., Jiokap Y., Parmentier M., and Dellacherie J, 1999, Acides gras et triglycerides du beurre du karité du Cameroun, Séminaire international sur le séchage et sur la valorisation du karité et de l'aiélé, à l'ENSAI (Ecole Nationale Supérieure des Sciences Agro Industrielles), Ngaoundéré (Cameroun), 1-3 décembre 1999, Editeurs: Kapseu $\mathrm{C}$ and Kayem J., pp 135-143.

[4] Boateng R., 2005, Databank Research, Agro-Processing, Accra, Ghana, pp 1-13.

[5] Mbaiguinam M., Mbayhoudel K., and Djekota C., 2007, Physical and chemical characteristics of fruits, pulps, kernels and butter of shea Butyrospermum parkii (Sapotaceae) from Mandoul southern Chad, Asian J. Biochem., 2: 101 - 110.

[6] Palmberg G., 1985. L'échantillonnage dans la récolte des semences forestières. Amélioration génétique des arbres forestiers. Cours de formation FAO/DANIDA Mérida Venezuela. Janv.-Fev. 1980, Etude FAO, Forêts 20, Rome 1985, pp 44- 48.

[7] INADES - Formation, 2009. Etude du potentiel karité au Tchad, BIOCONS, pp 7 - 9. 
[8] Krist, S., Bail, S., Unterweger, H., Ngassoum, M. B., Mohagir, A. M., and Buchbauer, G., 2006. "Volatile compounds of original African black and white shea butter from Tchad and Cameroon", Eur. J. Lipid Sci. Technol.,vol.108, pp. 583-588.

[9] Adoum D., 1996. Technique artisanale d'extraction du beurre de karité à Moyen Chari sud du Tchad, Actes du séminaire atelier oléagineux et petites technologies II, 23-27 Septembre 1996, «APICA, ENSAI», Editeur: André Eberrad, pp 9296.

[10] Beauvilan A., 1994, Tableau de la pluviometrie dans les bassins du Tchad et de la Benoue, Centre National d'Appui à la Recherche (CNAR), 103p.

[11] Pias J., 1956. Les formations sédimentaires de la cuvette Tchadienne et les sols qui en dérivent, Office de la Recherche Scientifique et Technique Outre-Mer (ORSTOM), pp 58-63.

[12] Lovett P., 2004, The shea butter value chain 'Refining in west Africa', United States Agency for International Development (USAID), WATH (West Africa Trade Hub) technical report No 2, 52 p.

[13] IUPAC (International Union of Pure and Applied Chemistry) , 1979, Méthodes d'analyse des matières grasses et dérivées, $6{ }^{\text {ième }}$ édition, 1 ière partie 1.122, Institut des Corps Gras, Bordeaux, France.

[14] Tchiegang, C., Aboubakar, D., Kapseu C., \& Parmentier, M., (2003). Etude des conditions d'extraction de l'huile par pressage des amandes de Ricinodendron heudelotii (Bail.) Pierre ex Pax, Journal of Food Engineering, 58: 363-371.

[15] AFNOR, 1981. (Association Française pour la Normalisation); « Recueil des normes françaises, Corps gras, graines

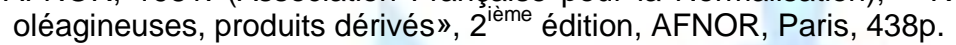

[16] Sonntag N., 1982, Analytical methods, in: Bailey's Industrial Oil and Fat Products, (Edt. Swern, D), John Wiley and Sons, U.S.A., Vol.2, $4^{\text {th }}$ ed., pp 431-488.

[17] El Warraki, A. G., 1995, Technology of oils and fats 'Extraction of oils and fats', King Saud University, Kingdom of Saudi Arabia, (Arabic copy), pp 71-154.

[18] Krishnamurty, R. G., 1982. Cooking oils, salad oils and dressings, In: Bailey's Industrial Oil and Fat Products, (Edt. Swern, D), John Wiley and Sons, U.S.A., New-York, pp, 315-341.

[19] Anwar F., Anwar T., and Mahmood Z., 2005. Methodical characterization of rice (Oryza sativa) bran oil from Pakistan, Grasas y Aceites, Vol. 56, pp 125 - 134.

[20] Womeni H. M., Ndjouenkeu R., Kapseu C., Mbiapo F. T., Parmentier M., and Fanni J., 2006, Effet de la cuisson et du sechage de noix de karité (Butyrospermum parkii (G. Don) Kotschy) sur la qualité du beurre, Tropicultura, 24 : 175 182

[21] Norris F. A., 1982, Extraction of fats and oils, in: Bailey's Industrial Oil and Fat Products, "Swern D., (Ed.)", Vol. $2,4{ }^{\text {th }}$ ed., John Wiley and Sons, New York, pp $179-188$

[22] Ladurelle H. (1984). Le Beurre de karité, Thèse de Doctorat en Pharmacie, Université Scientifique et Médicale de Grenoble, France 126p. 